\title{
GEOPHYSICAL ANALYSIS OF THE LITHOSPHERE BENEATH THE SLAVE CRATON
}

\author{
Yvette H. Poudjom Djomani ${ }^{1}$, Suzanne Y. O'Reilly ${ }^{1}$, William L. Griffin ${ }^{1,2}$ and Buddy J Doyle \\ ${ }^{I}$ GEMOC ARC National Key Centre, Department of Earth and Planetary Sciences, Macquarie University, Sydney, \\ Australia; ${ }^{2}$ CSIRO Exploration and Mining, North Ryde, Australia; ${ }^{3}$ Kennecott Canada Exploration Ltd, Vancouver, B.C., \\ Canada
}

\section{REGIONAL GEOLOGY}

The Slave craton is a small and well-exposed Archean nucleus within the larger Canadian shield (figure 1). It is bounded on the east by the Thelon continental marginal magmatic arc (2.0-1.9 Ga) that defines the western edge of the Archean Rae Province and on the west by the Great Bear magmatic arc of the Wopmay Orogen (1.88-1.84 Ga). The northern and north-eastern boundary of the Slave craton is defined by the overlapping Upper Proterozoic and Phanerozoic supracrustal rocks of the Canadian Arctic. On the south, the Slave craton is separated by the large Great Slave Lake Shear Zone from the Lower Proterozoic Chinchaga and Buffalo Head terranes.

\section{MANTLE STRUCTURE FROM GEOCHEMICAL DATA}

Xenoliths and heavy mineral concentrates have been used to map the composition, structure and thermal state of the lithospheric mantle beneath the Las de Gras area on the Slave craton (Griffin et al., 1999). This analysis revealed a distinct two-layered lithosphere beneath the Slave craton: a shallow ultradepleted layer and a deeper less depleted layer. The two layers are separated by a sharp boundary at $140-150 \mathrm{~km}$ depth (figure 1). Griffin et al (1999) interpreted the lower layer as plume material accreted from the lower asthenosphere. This interpretation is consistent with the presence of abundant lower-mantle inclusions in diamonds from the region (Davies et al., 1999). The base of the petrological lithosphere defined from xenolith data is at about $190 \mathrm{~km}$ (Kopylova et al., 1998).

\section{PREVIOUS GEOPHYSICAL ANALYSIS}

Seismic tomography results on the Slave craton place the lithosphere-asthenosphere boundary at $250 \pm 50 \mathrm{~km}$, consistent with petrological and magnetotelluric studies (Jones et al., 2001). The highest seismic velocities are found on the CSBC, showing that this lithospheric bloc is distinct from the adjacent terranes to a depth of
$150 \mathrm{~km}$ into the mantle. Shallow low-velocity anomalies are found between the Central Slave Basement Complex and the eastern edge of the craton. These anomalies are interpreted as trapped regions of fertile mantle material (lherzolite-rich) within the surrounding harzburgitic lithosphere.

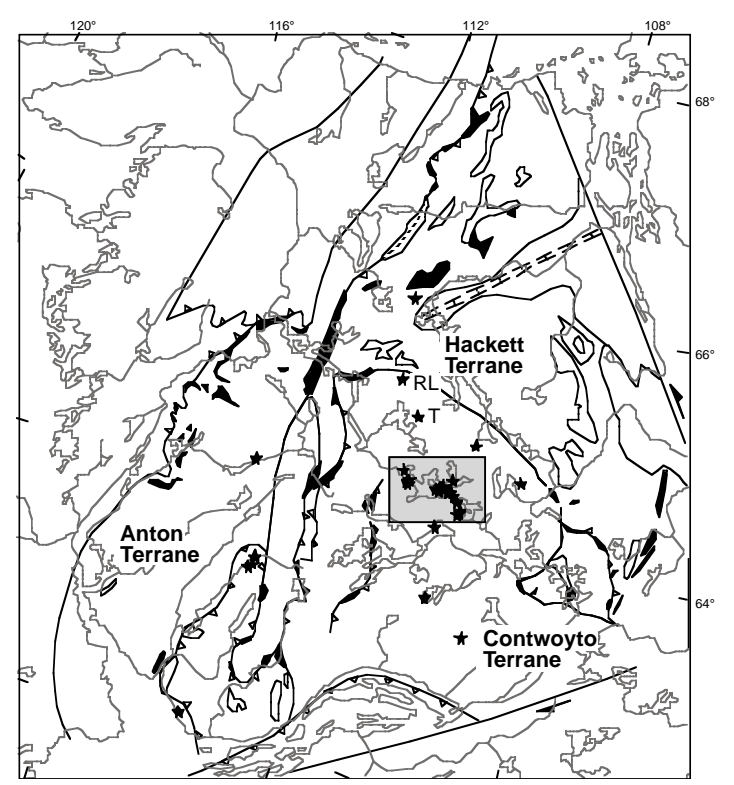

Figure 1: Regional geology of Slave Craton showing the ancient continental fragment of the Anton Terrane (or Central Slave Basement Complex) in the west, and the accretionary Hackett and Contwoyto terranes in the east. Dotted areas are Proterozoic sediments overlapping the craton. Kimberlites shown by stars: RL is Ranch Lake, $\mathrm{J}$ is Jericho, TN is Tenacity. The box in the centre is the central Lac de Gras area.

Jaupart et al. (1998) used heat flow and radioactive heat production data to estimate the crustal heat production and the mantle heat flow on the Canadian shield. Their results give an average mantle heat flow of $13 \mathrm{mw} / \mathrm{m}^{2}$ on the craton. Considering a thermally stable lithosphere, this heat flow value requires a compositionally defined lithosphere to be less than 240 $\mathrm{km}$ thick. This is consistent with the results of lithosphere thickness from other studies. 


\section{GRAVITY ANOMALIES ON THE SLAVE CRATON}

In this study, we enhanced gravity data to map largescale structures on the Slave craton. A map of the Bouguer gravity data upward continued to $100 \mathrm{~km}$ shows long wavelength negative Bouguer anomalies on the central part of the craton, correlating with the major kimberlite fields (figure 2). The northern part of the craton is characterized by relative positive anomalies, which probably reflect the head of the MacKenzie plume that produced major dyke swarms across the craton. Maps of vertical and horizontal derivatives of the Bouguer anomalies highlight NS-oriented structures (eg the eastern and western margins of the craton), as well as near EW-oriented structures (eg Great Slave Shear Zone).

Slave craton gravity upward continuation (100 km)

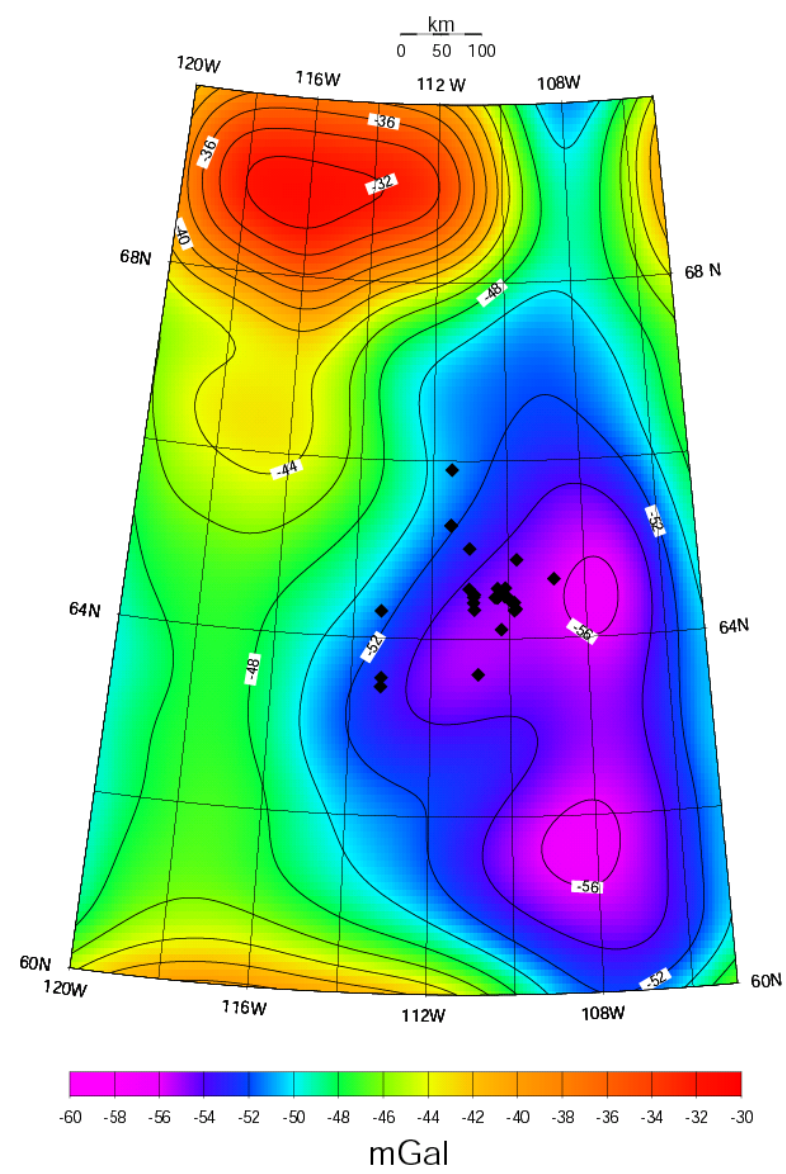

Figure 2: Bouguer gravity anomalies of the Slave craton and surroundings upward-continued to $100 \mathrm{~km}$ to emphasize longwavelength features. Black diamonds are kimberlites. Large negative anomalies reflect sub-crustal mass deficits which may correlate with ultradepleted upper mantle.

\section{RESULTS OF OUR TE ESTIMATES}

We invert gravity and topographic data to estimate the flexural strength or effective elastic thickness (Te) of the lithosphere of the Slave craton. The regional Te map shows variations from $14 \mathrm{~km}$ to $66 \mathrm{~km}$ (figure 3). The northern part of the craton is characterized by a relatively weak lithosphere $(T e<25 \mathrm{~km})$ surrounded by stronger lithosphere, the strongest being in the eastern part of the craton $(T e>56 \mathrm{~km})$.

Comparing the elastic thickness and other datasets

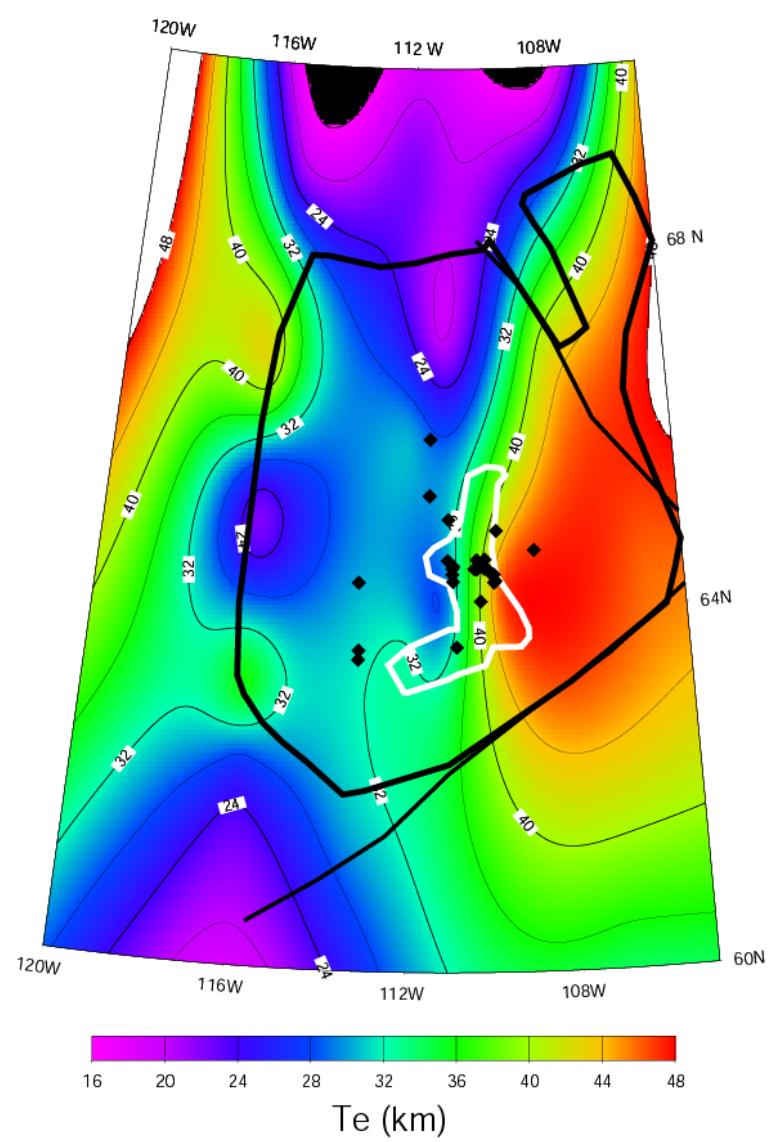

Figure 3: Contour map of Effective Elastic Thickness with outline of the Slave craton. Black diamonds are kimberlites. White outline is the minimum extent of the zone of high mantle conductivity mapped by Jones et al. (2001) which lies within the area of two-layered lithospheric mantle identified by our lithospheric mapping (Griffin et al., 1999).

A zone of low Te (oriented N-S) defines the western edge of the strong lithosphere to the east of the craton. The zone of Te gradient corresponds to the area where long-period magnetotelluric studies have defined a strongly conductive upper mantle, and also correlates 
with mantle region characterized by an ultra-depleted upper layer underlain by a layer of "normal" Archean mantle composition. The diamond fields on this part of the Slave Province are concentrated along the zone of strong $T e$ gradient and anomalous mantle conductivity. This zone appears to be geochemically and geophysically anomalous and to represent a major lithospheric discontinuity on the Slave craton. It may map the deep extension of the suture between the ancient continental block (up to $4 \mathrm{Ga}$ old) making up the western part of the craton, and the younger (2.7-2.9 $\mathrm{Ga}$ ) accreted terranes that make up the eastern part. The distribution of kimberlite fields suggests that this deep structure has provided pathways that enabled deepseated magmas to reach the surface over a period of time ranging from the Paleozoic to the Tertiary.

\section{REFERENCES}

Bank, C.-G, Bostock, M.G., Ellis R.M, Cassidy J.F., 2000. A reconnaissance teleseismic study of the upper mantle and transition zone beneath the Archean Slave craton in NW Canada, Tectonophysics, 319, 151-166.

Cook, F.A., van der Velden, A.J., Hall K.W., Roberts B.J., 1999. Frozen subduction in Canada's Northwest territories: Lithoprobe deep lithospheric reflection profiling of the western Canadian shield, Tectonics, 18(1), 1-24.

Durrheim, R.J., Mooney, W.D., 1994. Evolution of the Precambrian lithosphere: seismological and geochemical constraints, J. Geophys. Res., 99, 15359-15374.

Griffin, W.L., Doyle, B.J., Ryan, C.G., Pearson, N.J., O'Reilly, S.Y., Davies, R.M., Kivi, K., van Achterbergh, E., Natapov, L.M., 1999. Layered Mantle Lithosphere in the Lac de Gras Area, Slave Craton: Composition, Structure and Origin. Jour. Petrol., 40, 705-727.

Jaupart, C., Mareschal, J.C., Guillou-Frottier, L., Davaille, A. 1998. Heat flow and thickness of the lithosphere in the Canadian shield, J. Geophys. Res., 103, 15269-15286.

Jones, A.G., Ferguson, I.J., Chave, A.D., Evans, R.L., McNeice, G.W., 2001. The electric lithosphere of the Slave craton, Geology, 29, 423-426.

Kopylova, M.G., Russel, J.K., Cookenboo, H., 1998. Petrology of peridotite and pyroxenite xenoliths from the Jericho kimberlite: Inferences for the thermal state of the mantle beneath the Slave craton, northern Canada, Jour. Petrol.

Perry, C., Eaton, D., Forte, A., 2000. LITH5.0: preliminary 5 x 5 spherical spline crustal model for Canada, Lithoprobe workshop.

Contact: Yvette Poudjom Djomani, GEMOC ARC National Key Centre, Department of Earth and Planetary Sciences, Macquarie University, Sydney NSW 2109, Australia, E-mail: ypoudjom@els.mq.edu.au 